\title{
GLOBAL CITIZENSHIP EDUCATION: PARENTS’ REFLECTIONS
}

\author{
Vaida Žegunienè \\ Klaipeda University, Lithuania
}

\begin{abstract}
The paper aims to contribute to the understanding of the concept global citizenship education. Global citizenship education is defined as democratic and sustainable education that pursues to educate a global citizen who is able to perceive the processes of the modern society, to demonstrate a positive attitude and to adapt to the global environment.

It is emphasised that global citizenship is a factor ensuring development of a global citizen and his/her functioning within the global context. The analysis of the European and Lithuanian documents revealed that global citizenship education has to be initiated at the pre-primary school because children aged 5- to 7-years are capable to form/construct new global skills. Thus, to have global citizenship education integrated into the pre-primary school education is a must, but still gaps and obstacles exist.

The objectives of the research are to investigate how the parents of pre-primary school aged children perceive the concept global citizenship. Data for this research were collected using the qualitative method - an interview. A major advantage of an interview is that this method allows to investigate parents' individual perception of global citizenship education.

The most interesting aspect of the data gathered is that parents do not demonstrate complete understanding of global citizenship education and majority of them are not completely familiar with this phenomenon. They relate global citizenship education to travelling and living abroad, to knowledge of other countries/cultures and specific social issues such as pollution, discrimination, poverty. Taking into consideration the complexity of this process the parents' perception is insufficient. Therefore, further study has to be initiated regarding teachers' attitude to initiation and implementation of global citizenship education into the curriculum of the pre-primary school.
\end{abstract}

Keywords: global citizenship education, pre-primary school age, education, parent's perception.

\section{Introduction}

In the constantly developing global life of society a new trend of global citizenship became the main concern of the education system. It is important due to a rapid change in the educational needs and wishes of learners despite their age. There is a growing number of the European and Lithuanian documents regulating the education policy that acknowledges the great significance of global education and its specific aspect - global citizenship education. (Maastricht Global Education Declaration, 2002; Statement on Development Education and 
Awareness Raising, 2004; Strategy for Education for Sustainable Development 2005; White Paper on Intercultural Dialogue, 2008, Conception of Global Education, 2015; Lietuva ir globalusis švietimas, 2017; Resolution on the implementation of the sustainable development goals of the united nations in Lithuania, 2018; Innovation strategy for education and training, 2018). Having reviewed the situation in the international and national contexts and having analysed the definitions and in-depth explanations of the concept global citizenship, it has been admitted that global citizenship education is widely discussed by the educators, practitioners and scholars. Initiation and implementation of global citizenship education is recommended to be started at the pre-primary school (5- to 7-years old children) (Chaput \& Arnold, 2010; Jorgenson, 2010; Symeonidis, 2015; Augustinienè \& Pocienè, 2016; Hainsworth, 2017; Sy, 2017; Tarozzi, 2016).

The scope of global citizenship education includes various scientific, personal and professional fields of the modern life. Thus, it leads to the necessity to acquire new knowledge, develop/construct new skills and strengthen inner motivation to become and act as a global citizen. The specific issue will be addressed focusing on the complexity of global citizenship education: Do parents, of the of 5- to 7-years old children understand the essence and integral dimensions of global citizenship education? This research seeks to investigate the parents' perception of global citizenship education.

The article employs the methods of content analysis that allows to review the most important documents of the EU and the Republic of Lithuania concerning the definition and dimensions of global citizenship education; synthesis and generalization will be used for provision of detailed overview of the concept and its complexity. The qualitative research design and the method of interview are applied to investigate parents' perception of global citizenship education.

\section{Theoretical Analysis of the concept Global Citizenship Education}

In the era of constant globalization and internationalization modernized humanity has been raising questions and expressing concerns regarding global education and meaningful citizenship as well as about its global dimensions. Empowering learners to become active global citizens is a key issue of many international institutions and organizations that take measures concerning implementation of the global education throughout the whole world. Global citizenship education is an integral part of global education and a specific type of education enabling a learner to become a global citizen. It equips learners with the necessary knowledge, values, attitudes and skills to understand, create and sustain people's lives locally, nationally and globally (UNESCO, 2013, 2014a, 2014b, 2015, 2017). 
The twenty-first century schools must cope with new questions related to internationalization of curriculum and meeting new demands of the young learners and to revisit their thinking and action frameworks. As the European documents emphasize global citizenship education is based on the belief that globalization is a new world paradigm; it functions as an interconnected system that influences how citizenship operates. The global frame does not replace attention to national and local issues. Rather this frame re-orients citizenship education so that learners become aware of the issues and the factors at many levels that shape the world around them. Global citizenship refers to a sense of belonging to a broader community and common humanity and aims to be transformative, building the knowledge, skills, values and attitudes that learners need to be able to contribute to a more inclusive and peaceful world. This process of education takes a multifaceted approach, employing concepts and methodologies including human rights education, peace education, education for sustainable development and education for international understanding and aims to advance their common objectives (CONCORD, 2004; UNESCO, 2013, 2014a, 2014b; IBE-UNESCO, 2018; OECD, 2018).

Global citizenship education should be started to be implemented beginning from early childhood and continuing through all levels of education and into adulthood, requiring both 'formal and informal approaches, curricular and extracurricular interventions, and conventional and unconventional pathways to participation (UNESCO, 2017). As K. Mundy (2007) notes very young age children are enculturated into their local culture, but nowadays this process might be combined with the opposite process of acculturation. Children's thinking, worldview, norms, values beliefs etc. are shaped in a different way due to globalization. These interconnected processes direct young learners to a global living style and children tend to be more open for the global society (Mundy, 2007). Great thinkers such as Vygotsky (1991), Piaget (2007) and Dewey (2011) all agree that children's social experiences are highly influential and offer transformational opportunities. Precisely speaking, the result of becoming a global citizen may be achieved just through a social interaction. Thus communicating (interacting) to each other and making influence on knowledge acquisition (construction), interpretation and combination with previous experience enable a pre-primary aged child to become a proactive citizen of the world (Dewey, 2011).

In an attempt to develop a precise definition for global citizenship education, OXFAM (2007) suggested that a 'global citizen' is someone who:

- $\quad$ is aware of the wider world and has a sense of their own role as a world citizen;

- $\quad$ respects and values diversity; 
- $\quad$ has an understanding of how the world works economically, politically, socially, culturally, technologically and environmentally;

- $\quad$ is outraged by social injustice;

- $\quad$ is willing to act to make the world a more equitable and sustainable place;

- $\quad$ participates in and contributes to the community at a range of levels from the local to the global (Oxfam, 2015, 5).

Constructions of childhood, early childhood education practices, and approaches to early childhood education all lead to understandings about a 'child as a citizen.' Children in classrooms around the world are engaged in learning which focuses on civic responsibility, environment protection, human rights, norms and values, willingness to help and participate in various social activities, etc., including many of the aforementioned characteristics of a global citizen, from a very young age (Twigg, Pendergast, \& Twigg, 2015, 79).

To sum up, early childhood is an important period in which personality is shaped and universal morality is structured. It has to become a necessity to educate individuals in terms of the freedoms and responsibility in societies which are not limited only to themselves. It would be possible to achieve such an aim via the integration of global citizenship with early childhood education. Global citizenship aims to structure the world for living in peace through love, respect, understanding and justice. In the world in which inequality is on the stage, creating awareness and sensitivity in terms of an individual's part in the whole world from their early years can be the key.

\section{Research Design}

The methodological approach taken in this research is a qualitative research methodology. The method of interview was used for gathering information. The interview was initiated aiming to talk to the participants (parents) about the main object - global citizenship education. The aim was to investigate how the parents of pre-primary school aged children perceive the mentioned concept and what they think means to be a global citizen. The method of interview was used intentionally, as K. Kardelis (2007) notes the qualitative methods provide a researcher with a possibility to penetrate into the essence of the phenomena. An interview creates favorable circumstances to analyze individuals' expressed ideas when they act in the natural setting and the phenomena is interpreted using daily individuals' language. When an interview is organized and initiated the information can be obtained in a pleasant environment, the participants can freely express their concerns, talk about own experience, values and beliefs. 
The research used semi-structured purposeful interview (Patton, 1990) where questions and their sequence were foreseen in advance, but a researcher could ask additional questions not included into the list of pre-prepared questions aiming to reveal the essential points of the research object. Such interview is called purposeful (Patton, 1990), a researcher has a possibility to be more flexible with questions to be asked and words to be used. L. Rupšienė (2007) emphasizes importance to be an active listener and to probe participants. The negative aspect might be getting sidetracked from the main topic, when a participant does not follow the desired course of the questions and skips the direct answers.

Preparation. The basic questions have been foreseen and prepared by the researcher such as How do you understand the concept global citizenship education? What main ideas come to your mind when you think about this concept? What dimensions may be discussed talking about global citizenship education? Such questions may reveal the parents' perception of global citizenship education, or at least the integral dimensions of this process. Other questions might be asked to gather additional information: How do you understand the concept global citizen? Is your child capable to be and/or act as a global citizen? Does your child behave like a global citizen? The questions allowing to acquire more precise information on different aspects of the topic can be asked such as How do you understand...?, Do you see that as ....? Are these concepts similar or different? etc.

Sample. Three (3) informants have been recruited for this research. The sample of the qualitative research can be with few informants as noted by L. Rupšienè (2007). V. Žydžiūnaitė and S. Sabaliauskas (2017) demonstrated the same approach stating that the size of sample of qualitative research is not so relevant, but the main focus is on the interview content, the information recorded and gathered, the essential elements of the object to be revealed by the participants. It is proposed by the same scholars that it is significantly important to select unique participants and to disclose remarkable points. The participants were selected by the criteria as follows:

- $\quad$ have a 5- to 7-years-old child (children);

- $\quad$ are interested in educational innovations related to this age group;

- $\quad$ have a degree of higher education.

The first participant (P1) lives in Vilnius (Lithuania), has acquired the Bachelor degree (English Philology), has established a school of non-formal education for 5- to 7-years-old children; has a 5-years-old child.

The second participant (P2) lives abroad, migrated from Lithuania 4 years ago, has acquired the professional Bachelor degree (Food Processing), has a 7-years-old child. 
The third participant (P3) lives in Klaipeda (Lithuania), has acquired the Bachelor degree (Education), has a 6-years-old child.

\section{Research Results}

The interviews were recorded, transcribed, divided into segments and labeled. The main themes and topic related to the concept of global citizenship have been distinguished (see Table 1 and Table 2).

Table 1 Main themes and topics of the interview

\begin{tabular}{|c|c|c|}
\hline Interview questions & Main themes & Topics \\
\hline $\begin{array}{l}\text { How do you understand the concept global } \\
\text { citizenship? } \\
\text { What are the main elements (dimensions) of } \\
\text { global citizenship? } \\
\text { What main ideas come to your mind when } \\
\text { you think about this concept? } \\
\text { Does your child behave like a global } \\
\text { citizen? }\end{array}$ & $\begin{array}{l}\text { Knowledge } \\
\text { Values } \\
\text { Motivation }\end{array}$ & $\begin{array}{l}\text { World } \\
\text { Culture } \\
\text { Tolerance } \\
\text { Equality } \\
\text { Respect } \\
\text { Willingness to help }\end{array}$ \\
\hline
\end{tabular}

Table 2 Reflection of main themes/topics of the interviews

\begin{tabular}{|c|c|c|}
\hline Main theme & Topic & Citation \\
\hline Knowledge & $\begin{array}{l}\text { World } \\
\text { Culture }\end{array}$ & 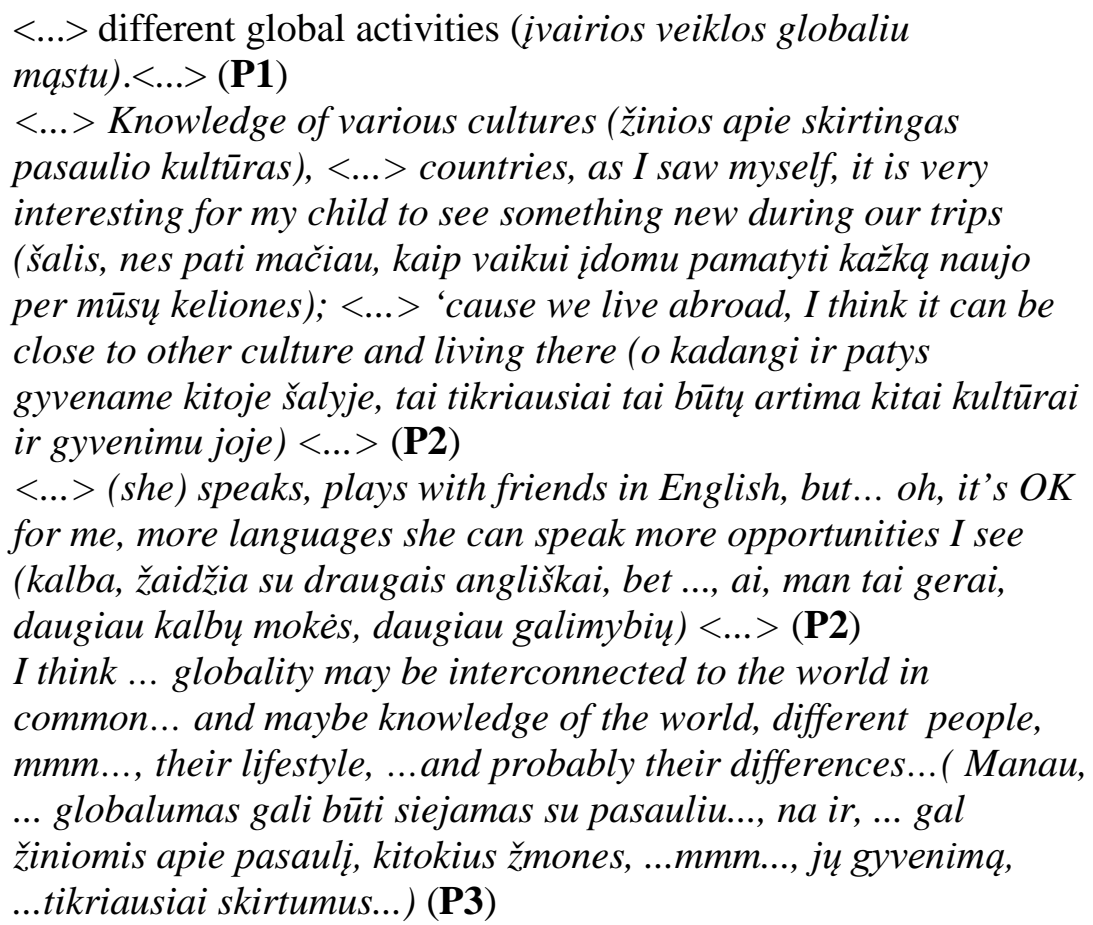 \\
\hline
\end{tabular}




\begin{tabular}{|c|c|c|}
\hline Values & $\begin{array}{l}\text { Tolerance } \\
\text { Respect } \\
\text { Care }\end{array}$ & 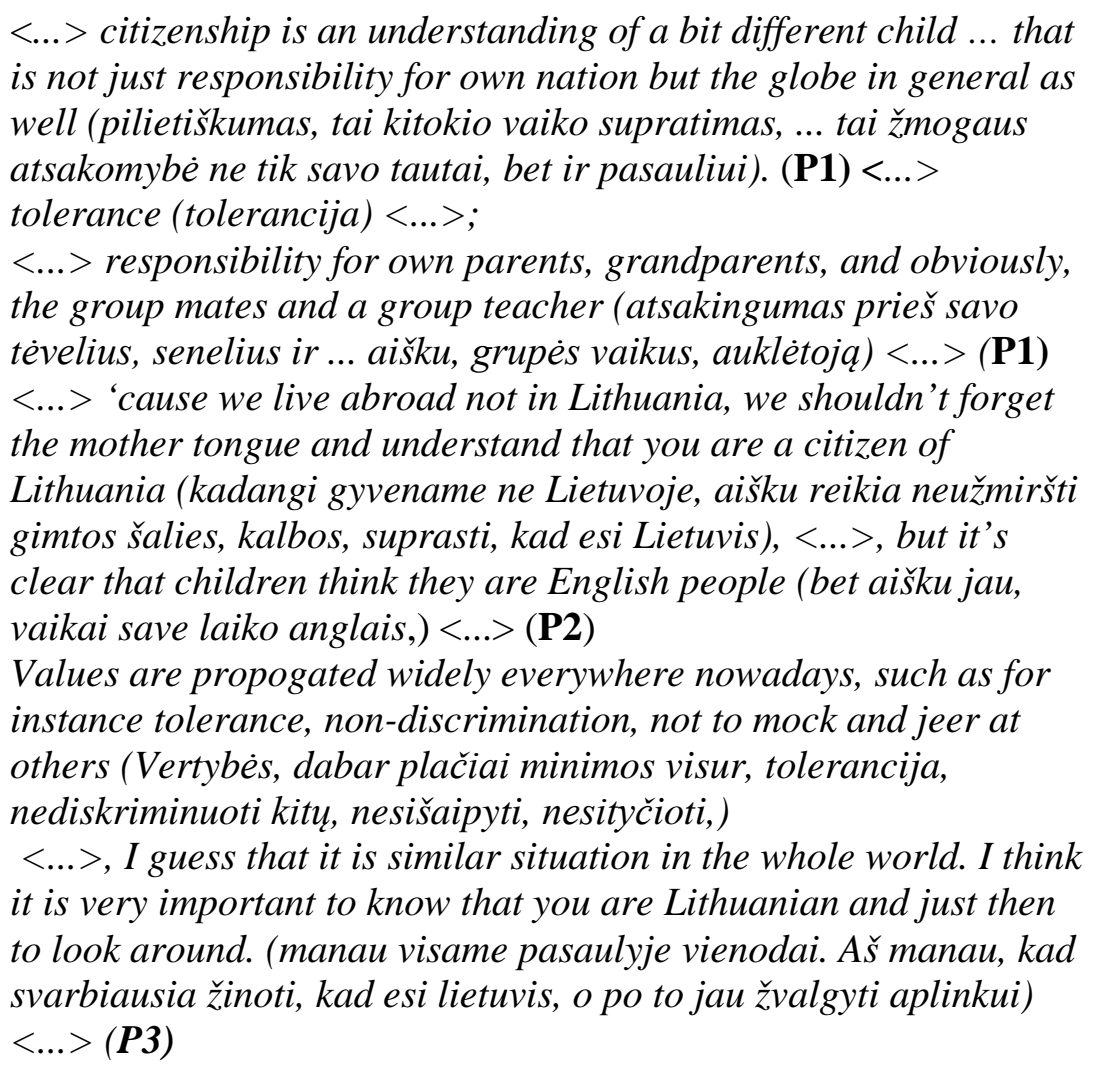 \\
\hline Motivation & $\begin{array}{l}\text { Willingness } \\
\text { to help }\end{array}$ & 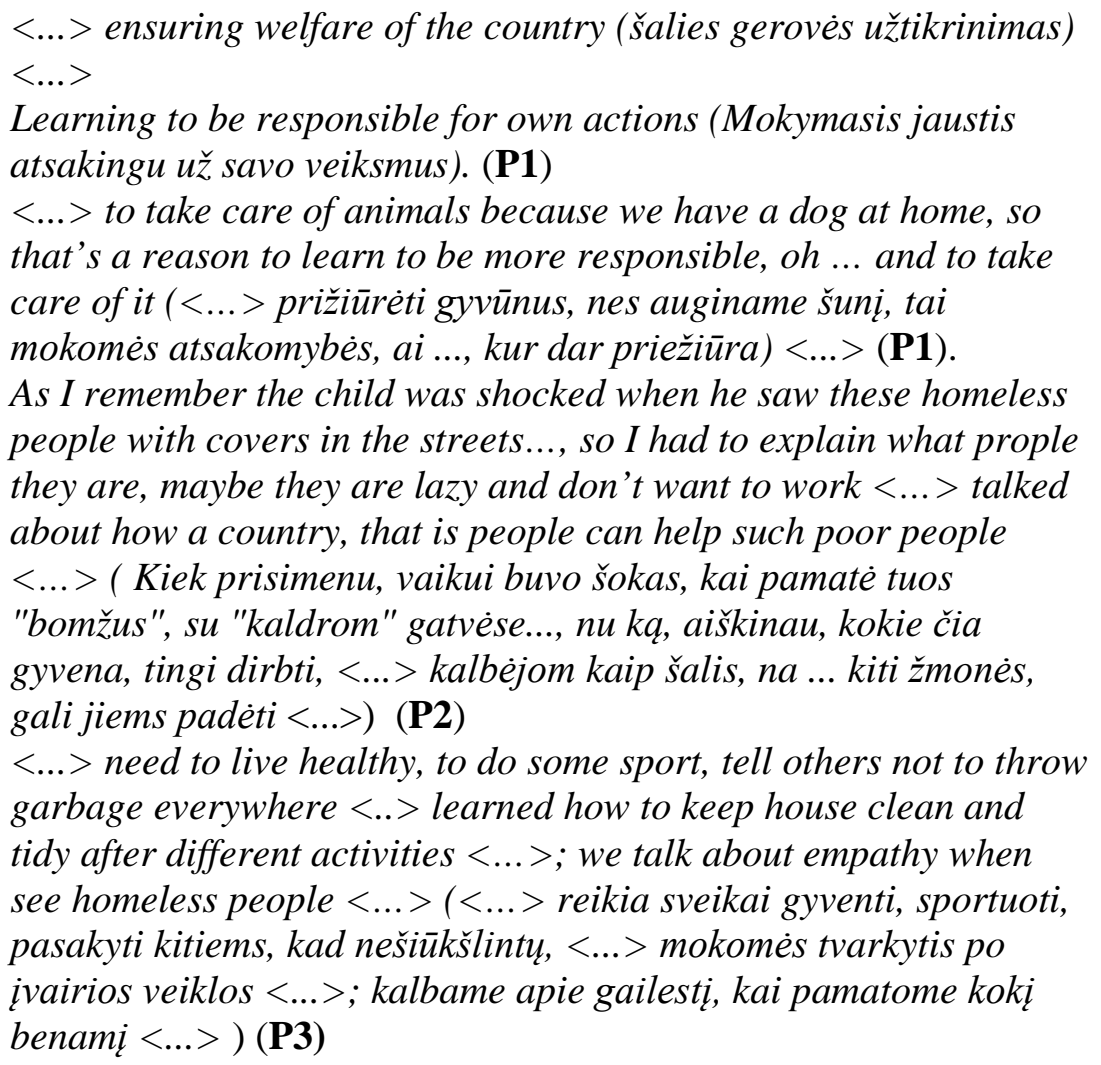 \\
\hline
\end{tabular}


The current research found that parents of 5- to 7-years-old children demonstrate incomplete understanding of the concept global citizenship relating that to knowledge of other cultures (Knowledge of various cultures...), lifestyles and people (I think ... globality may be interconnected to the world in common... and maybe knowledge of the world, different people, mmm..., their lifestyle, ... and probably their differences...) and/or travelling (..., it is very interesting for my child to see something new during our trips.) Some of them emphasized necessity to acknowledge that firstly a child is a citizen of Lithuania (his/her native country) (...ensuring welfare of the country...) and just then (s)he may (...look around...) and think or behave globally. Basically, the explanations of global citizenship were provided in the form of examples from children's behavior related to their daily activities outside the pre-primary school. Global citizenship was interpreted as familiarization with differences, different people existing in the world and dealing with the global social issues (homeless, poor people, unemployability) (...homeless people with covers in the streets...; need to live healthy, to do some sport, tell others not to throw garbage everywhere.); furthermore, that concept was related to care, help and responsibility for own actions and for other people (parents, grandparents, groupmates, and a group teacher) or animals (... to take care of animals because we have a dog at home, so that's a reason to learn to be more responsible, oh ... and to take care of it.) Parents' tend to discuss their role and actions taken as I had to explain..., we discussed..., we talked....

Surprisingly, one important finding was that beside parents' insights about complexity and possible dimensions of global citizenship a role of pre-primary school and teachers was not taken into consideration. Possible explanation might be that parents see themselves as the primary educators of children and the origin of global citizenship is based on the family background and interaction with parents, friends or relatives.

The research and interpretation of data leads to general assumption that the field of global citizenship education needs more precise analysis from different perspectives. Cooperation between school educators and parents is undeniable and it has to be initiated in both types of educational settings formal and nonformal. To develop a full picture of global citizenship education additional research will be needed to conduct with the pre-primary school educators.

\section{Conclusions}

The purpose of the current study was to determine the essential dimensions of global citizenship education taking into consideration the specific age group of learners. The evidence based on the theoretical analysis of the European and Lithuanian documents revealed the complexity of this concept and necessity to 
educate 5- to 7-years old children not as the citizens of their native country, but global citizen education has to be implemented in parallels.

Global citizenship education has to be an integral part of pre-primary school education curriculum aiming to develop a personality who is able to think critically, to understand the global aspect of global environment, to perceive personal role in the close and further surroundings and to be motivated to act in national and international context.

Returning to the question posed at the beginning of this research, it is now possible to state that global citizenship education is not appropriately understood by the parents of pre-primary school aged children. There are some gaps and obstacles for proper education at formal and non-formal settings. Basically, parents' perception and interpretation of this concept is based on daily life situations and there were no relations with the education at school. The findings clearly indicate that global citizenship education and being as a global citizen is just non-formal familiarization with the existing social issues, travelling, discussions with parents, taking care of friends, relatives and pets.

The research has also shown that firstly the parents see their children as the citizens of their native country (Lithuania) and secondly, children's knowledge may be expanded globally.

The results of this research support the idea that parents' perception of global citizenship is incomplete, this concept is more closely related to family background and the importance of the teachers' role was not considered. Due to these insights the further research of global citizenship education has to be initiated.

\section{References}

Augustinienè, A., \& Pocienè, T. (2016). Priešmokyklinio amžiaus vaiku žodyno turtinimo, taikant skaitmeninius mokymosi objektus, galimybès. Retrieved from https://vdu.lt/ cris/bitstream/20.500.12259/35166/1/ISSN2351-7409_2016_N_2.PG_43-58.pdf

Chaput, C., O’Sullican, M., \& Arnold, C. (2010). Neoliberal world: The potential of transformative education during a short-term study abroad course in Cuba. International Journal of Development Education and Global Learning, 2(3), 25-43. London: IOE Press.

Conception of Global Education. (2015) (Globaliojo švietimo koncepcija) Retrieved from https://www.upc.smm.lt > ugdymas > dokumentai > svarstomi > globalus

CONCORD. (2004). Statement on Development Education and Awareness Raising. Retrieved from https://ec.europa.eu/europeaid/sites/devco/files/publication-development-educationfor-the-european-consensus-200806_en.pdf

Dewey, J. (2011). Democracy and education. Simon \& Brown.

Europe Council. (2008). White Paper on Intercultural Dialogue. Retrieved from https://www.coe.int/t/dg4/intercultural/source/white\%20paper_final_revised_en.pdf

Europe Parliament. (2012). Declaration of the European Parliament of 5 July 2012 on development education and active global citizenship. Retrieved from 
http://www.europarl.europa.eu/sides/getDoc.do?type=TA\&language=EN\&reference=P7TA-2012-302

Hainsworth, J. (2017). The weight of children's opinion should be respected. Report on the State of Citizenship and Human Rights Education in Europe. Council of Europe, 43. Retrieved from https://rm.coe.int/the-state-of-citizenship-in-europe-e-publication/ $168072 b 3 c d$

IBE-UNESCO. (2018). Training Tools for Curriculum Development: A Resource Pack for Global Citizenship Education (GCED). The International Bureau of Education- United Nations Educational, Scientific and Cultural Organization: Switzerland. Retrieved from http://www.ibe.unesco.org/fileadmin/user_upload/Publications/Training_tools/IBE-CRP2014_eng.pdf

Jorgenson, S. (2010). De-centering and Re-visioning Global Citizenship Education Abroad Programs. International Journal of Development Education and Global Learning, 3(1), 23-38.

Kardelis, K. (2016). Moksliniu tyrimy metodologija ir metodai. Vilnius: Mokslo ir enciklopedijų leidybos centras.

Mundy, K. (2007). Charting global education in Canada's elementary schools: Provincial, district and school level perspectives, 9. Retrieved from https://www.unicef.ca/ sites/default/files/imce_uploads/UTILITY\%20NAV/TEACHERS/DOCS/GC/ChartingGl obalEducationinElementarySchools.pdf

Maastricht Global Education Declaration, (2002). Retrieved from https://rm.coe.int/ $168070 \mathrm{e} 540$

OECD. (2018). Innovation strategy for education and training. Paris, France. Retrieved from https://www.oecd.org/education/ceri/IS_Project_Brochure.pdf

Oxfam. (2015). Education for Global Citizenship. A Guide for schools. Retrieved from https://www.oxfam.org.uk/education/resources/education-for-global-citizenship-a-guidefor-schools

Patton, M. (1990). Qualitative evaluation and research methods. SAGE Publications. Newbury Park London New Delhi.

Piaget, J. (2007). The childs conception of the world: a 20th century classic of child psychology. Rowman \& Littlefield publishers.

Resolution on the implementation of the sustainable development goals of the United Nations in Lithuania. (2018). Retrieved from https://e-seimas.lrs.lt/portal/legalAct/lt/TAD/ ad987682d21011e8a82fc67610e51066?jfwid=-35aaxip3i

Rupšiene, L. (2007). Kokybinio tyrimo duomenu rinkimo metodologija: metodine knyga. Klaipèda: Klaipėdos universiteto leidykla.

Symeonidis, V. (2015). Towards Global Citizenship Education. Retrieved from https://www.researchgate.net/publication/305947018_Towards_Global_Citizenship_Edu cation_A_comparative_case_study_of_primary_school_policy_and_practice_between_G reece_and_Sweden

Sy, A.E. (2017). Connecting citizenship and human rights education to everyday life. Report on the State of Citizenship and Human Rights Education in Europe. Council of Europe, 43. Retrieved from https://rm.coe.int/learning-to-live-together-council-of-europe-report-onthe-state-of-cit/1680727be5

Tarozzi, M. (Ed.) (2016). Global Citizenship Education in Europe. A Comparative Study on Education Policies across 10 EU Countries. Research deliverable issued within the European project “Global Schools”, Trento, Italy: Provincia Autonoma di Trento. 
The United Nations Secretary-General. (2012). The United Nations Global Education. First Initiative (2012-2016). To build a better future for all. Retrieved from http://www.unesco.org/new/en/gefi/about/

Twigg, D., Pendergast, D., \& Twigg, J. (2015). Growing global citizens: Young children’s lived experiences with the development of their own social world. International Research in Early Childhood Education, 6(1), 79.

UNESCO. (2013). Global Citizenship Education. An emerging perspective. Outcome document of the Technical Consultation on Global Citizenship Education. Retrieved from https://unesdoc.unesco.org/ark:/48223/pf0000224115

UNESCO. (2014a). Education Strategy 2014 - 2021, 46. Retrieved from https://unesdoc.unesco.org/ark:/48223/pf0000231288

UNESCO. (2014b). Global citizenship education: Preparing learners for the challenges of the 21st century. Retrieved from https://unesdoc.unesco.org/ark:/48223/pf0000227729? posInSet=1\&queryId=36cccc9a-72ad-4fae-86f8-d718798fc515

UNESCO. (2015). Global Citizenship Education. Topics and Learning Objectives. France: Paris. Retrieved from https://unesdoc.unesco.org/ark:/48223/pf0000227729?posInSet= 2\&queryId=22c96697-9630-403c-b4212c4d05550866

UNESCO. (2017). ESD and GCED in national curriculum frameworks. Retrieved from http://www.unesco.org/new/fileadmin/MULTIMEDIA/FIELD/Nairobi/esdgceden.pdf

Vygotsky, L.S. (1978). Mind in society: The development of higher psychological processes. Cambridge, MA: Harvard University Press.

Žydžiūnaitè, V., \& Sabaliauskas, S. (2017). Kokybiniai tyrimai. Principai ir metodai. Vilnius: Vaga. 
